\title{
Innovative VAT Income Deduction Policy and Accounting Process from the Perspective of Technical Innovation*
}

\author{
Yi Tang \\ Guangdong University of Science and Technology \\ Dongguan, China 523083
}

\begin{abstract}
On the strategic background of innovation driving development, based on the basic analysis of valueadded tax deduction and the function of value-added tax optimizing the economy, this article raises to increase the labor costs for internal $R \& D$, amortization of depreciation of long term assets used directly for $R \& D$, income deduction for amortization of technical intangible assets, as well as making corresponding adjustment on accounting so as to stir the R\&D, promote the technological progress and economic transition and upgrade.
\end{abstract}

Keywords - technical innovation; VAT deduction; deduction accounting process

\section{INTRODUCTION}

\section{A. Background for Reform and Innovation}

Currently the global technological revolution and the industrial revolution will be further pushed, and the world economy is in a deep adjustment. And China is in a critical period where old and new drives are shifting and the industrial structure is under adjustment, Fifth Plenary Session of the Eighteenth Central Committee of the Party, The five development concept, stressed that "must be the leading role in the development of innovation, the innovation in the national development of the overall core position" for China's "thirteen" period of economic and social development provides guidance. the Fifth Plenary Session of the 18th Central Committee of the CPC raised timely five innovation-based development philosophies from a strategic height, stressing that "We must regard innovation as the first driver for development and put it in the core position for the overall development of the country", which provides direction for the economic development during the 13th fiveyear plan. Any innovation shall be based on science and technology, which however is risky and vulnerable to external factors, and the results cannot be predicted. In order to lower risks of technological innovation and reduce costs for innovation, we encourage the technological innovation to drive the economic transformation and upgrade, and

*Project: Guangdong College Key Scientific Research Project (2015GXJK163)

Guangdong Dongguan Philosophy and Science Topic Achievements (2017ZDZ12) authorities should do what they should do. Technological innovation isn't going on one way or isolated, which needs the support of laws, rules and polices. As policy and law makers, authorities are required to provide scientific, rational and targeted rules to promote the innovation. The Overall Plan for Further Deepening Financial and Taxation System Reform ${ }^{1}$ points out, we have to further deepen the financial and taxation system reform, improve the taxation function, establish a taxation system which do good to scientific development, social fairness and unified market, fully exert the functions of taxes to collect financial revenue, adjust distribution and optimize the structure.

\section{B. Tax Circumstances of Enterprises at Home}

Complaints and debates concerning heavy taxation on enterprises at home have been lasting for a long time, most recently, king glass Cao Dewang and Zong Qinghou, founder of Wahaha Group said in an interview that Chinese enterprises bear heavy taxation, which triggered mass debates about the heavy taxes at home. Dec 21, 2016, on the 78th NSD policy talk forum titled the Central Economic Work Conference and 2017 Economic Policy held at Long Run Park, Peking University, where Yao Yang, president of National School of Development at Peking University made a speech, titled Economic Work Task for Next Year, which pointed out, though two taxes (business tax and VAT) are merged, looking like 50 million yuan is saved for enterprises, actually the VAT is still a little higher, so most of us complain the high costs. If medium and small enterprises pay all taxes as required, most are unable to survive, the high VAT causes higher taxes for commodities produced at home and the higher prices ultimately, consequently consumers are unwilling to purchase at home but would rather purchase consumables at low-rate countries or no-tax regions, which do bad to stir consumption at home. Yang Yuanqing, member of the national committee of CPPCC and president of Lenovo Group and CEO $(2013,2015)$ ever appealed at the grouping discussion meeting of national committee of CPPCC, reduce the VTA rate, create ideal consumption circumstances, avoid high prices at home but low ones

\footnotetext{
${ }^{1}$ Overall Plan for Further Deepening Financial and Taxation System Reform reviewed and approved at the meeting of the Political Bureau of the Central Committee of the CPC on Jun 30, 2014.
} 
abroad, and consumers are unnecessary to shop abroad. In fact, tax evasion has been an ordinary state for medium and small enterprises at home.

\section{Selection of Applicable Economic Adjustment Modes}

Main methods for governments to adjust industrial structure and organization modes include indirect inducement, direct interference, information instruction, law, rules and regulations (Li Wenjing et al, 2014)[1], the positive incentive measures for the economic structure control mainly include fiscal subsidies, tax preference and so on, yet the effects vary with measures. Seen from the time validity, the effect of fiscal subsidies are much more direct and rapid, yet the policy effect may decay and even distort the efficiency; yet the full exertion of tax preference policy may need a longer time, so we tend to get the long tern and steady effect through optimizing resource allotment (Zhao Guo, et al, 2016)[2]. Liu Shangxi, president of Chinese Academy of Fiscal Sciences under Ministry of Finance, points out that the unpredictable results of innovation requires that the incentive design of tax systems should start with behaviourism, and the system design shall be done on the basis of innovative behaviors so as to form an innovation friendly tax system(Liu Shangxi, Fan Yixia, 2016)[3].

As for how to reduce the taxes of enterprises and promote the economic transformation and upgrade, seen from the tax reform, we should optimize the tax structure, perfect the tax function, foster the tax sources and fully exert the roles of taxes to regulate distribution and optimize the economic structure.

\section{VAT NATURE AND ECONOMIC EFFECT}

Since its birth in France, VAT has been adopted in over 100 countries, which is an indirect tax mostly used around the world. In 1997, VAT started in China, after a series of tax reform in 1984, 1994, 2009, 2012 and 2016, we have completed the transformation from trial to production VAT to consumption VAT, which has spread to every trade and brought deep and wide influence to the society.

\section{A. VAT Deduction}

VAT is a circulation which is levied with the added value as objection of taxation that occurs during the circulation of commodities (labors), and a tax based on the balance of the sales income minus purchase costs. Yet the purchase costs are just part of the commodity (labor) costs, and the commodity (or labor) costs also include important internal labor costs, appreciation and amortization of long term assets, operation taxes and fees, which are not deducted when calculating the added value of VAT. Some enterprises deduct purchase costs, there is added value; yet when taking internal labor costs into consideration, there will be no added value. Therefore, the VAT payers may be not profits-making enterprises and possibly unprofitable ones. If the unprofitable enterprises have to pay VAT, seen from legal principles, the VAT design is not rational. Actually with the economic and social development, the proportion of costs of materials is decreasing yet the proportion of labor costs in commercial labor costs is increasing. Especially technical enterprises which are based on R\&D or are focused on a great number of R\&D generally technical products and service with high added value, the costs of raw materials are lower yet, the internal labor costs are relatively higher. Therefore, relatively according to the existing VAT policy, R\&D or technical enterprises have few income deduction but heavier VAT burden, which ultimately will cause adverse selection, unwilling to engage in $R \& D$, which will do bad to the development of new \& hi-tech industry.

\section{B. Economic Effect of Difference in VAT Rate}

Currently VAT rates are design to be $17 \%, 13 \%, 11 \%$ and so on, yet the difference in tax rate may possibly cause improper allocation of resources and efficiency loss, going against the basic requirements of simplifying taxes. The difference in tax rates has changed the relative prices between products and production factors, distorted behaviors of enterprises and consumers, causing efficiency loss ultimately, so when setting rate rates, we should do out best to set uniform tax rates for all products and service as possible as we can (Chen Xiaoguang, 2013)[4]. There are serious different VAT rates or export rebates in the VAT system in China, and the policies fail to well identify enterprises' characteristics, which finally cause improper allocation of resources in manufacturing and form efficiency loss (Jiang Wei, 2016)[5]. Different tax rates are designed for different enterprises for tax incentives, which are complained, however, in different stages, according to the need of economic and social development, priorities are really necessary to pay to some industries with taxes as incentives.

\section{VAT Deduction and New \& Hi-Tech Industrial Development}

Tax is one of the most tools for economic control in a country, and VAT owns the highest proportion in China. VAT executes tax payment via deduction (for general taxpayers), it may promote market players to continuously optimize themselves, grant the business they are not good at to others and enable the enterprises are engaged in the products and service that they excel in. The tax incentivebased innovation is widely used adopted around the world, especially in developed countries as UK, USA, Germany, Japan where more tax preferences are given. Current VAT has spread to every trade, which is the largest, the most important, the strictest tax with the deepest influence on the economy and society, we should well think that it is necessary to deeply understand its nature, grasp its causes and take the "Business Income To VAT" as a chance, further research and design so as to drive the development of new \& hi-tech industry needed urgently in the country and push the optimization and upgrade of industrial structure. Whether taxes are taken as a tool or policy, Will it flexible to take innovative VAT deduction as tax incentive to the development of key industries?

Key and crucial technologies mean speaking right and profit distribution, which cannot be bought. Currently China is facing double pressures of backflow of advanced 
manufacturing to developed countries and split-flow of lowcost competition in developing countries, besides, technical innovation is of high risk, if it is allowed to adjust freely by markets, it will be difficult for China to predominate in the global and regional economic competition.

\section{VAT DEDUCTION AND ACCOUNTING PROCESS REFORM ORIENTATION}

Seen in nature, VAT is to levy taxes on added value, the VAT paid by purchase costs can be taken as income deduction as required, yet internal costs are costs as well, which should be ducted as well according to legal principle, which is really to levy tax on the added value, meeting the basic requirements of added value. The tax structure adjustment and optimization can improve the fairness and efficiency of economic operation, better promoting the development of economy and society. The 13th five-year plan raised the innovation leading five development philosophies, requiring that we should take innovation as the first drive to boost the economic transformation and upgrade. Innovation shall be technical innovation centered overall renovation, including knowledge innovation, system innovation, mechanism innovation, culture innovation and so on, and fiscal taxation policies and accounting rules shall also follow the state development strategy---innovative drive, conduct corresponding reform innovation, stir enterprises R\&D innovation and boost the industrial upgrade.

As for the VAT, in order to encourage innovation and stir $\mathrm{R} \& \mathrm{D}$, reform innovation can be conducted on some tax policies and accounting rules so as to fully exert the roles of VAT to optimize the economic structure.

\section{A. The Deduction of $R \& D$ Labor Cost and the Innovation of Accounting Treatment}

Innovation comes from intellectual capital, and intellectual capital is the basis for practice of the concept of innovation and development. Without human, innovation is out of the question. Competition between enterprises is the competition of human capital, excellent intellectual capital is the real most scarce resources for enterprises. The more economic and social progress is, the higher the proportion of enterprise labor costs is, especially for the high-tech enterprises and research and development enterprises. According to the practice of current only deduction of outsourcing costs in value-added tax accounting, these enterprises take a disadvantageous position in comparison with traditional enterprises. In the critical period that current global technological revolution and industrial reform is profoundly and rapidly changing, the CPC Central Committee and the State Council issued Some Opinions on Deepening Institutional Reform and Accelerating the Implementation of Innovation-Driving-Development Strategy (March 13, 2015) to take scientific and technological innovation as the core of the whole national development and to regard the talent as the first resource for innovation, to adhere to the structural tax cuts, gradually transfer the investment way of the state in enterprise's technology innovation into the inclusive-type fiscal policy, and to emphasize more focus on the innovative function of skilled talents.

In order to implement the innovation-drivingdevelopment strategy, establish the innovation-drivingdevelopment model and encourage the development of science and technology enterprises, we can attempt to deduct the remuneration of researchers of enterprises on the current value-added tax deduction rules when we calculate the added value, increasing the deduction and reducing the tax burden, so as to encourage enterprises to employ scientific research personnel for research and innovation. In the internal R \& D outlay of China's industrial enterprises in 2014, the labor costs is 259866.67 million yuan $^{2}$, and if it is deductible, estimated as $17 \%$ tax rate, the labor expenses of $R \& D$ personnel can offset the tax burden of 44177.3339 million yuan for industrial enterprises .

When tax policy changes, accounting treatment should be also adjusted correspondingly adjustments, debit: R \& D expenditure, management fees, etc., debit: tax payable - input tax to be certified, credit: staff salaries payable. After the certification by tax bureau, and make another debit: tax payable - VAT payable (input tax), credit: tax payable input tax to be certified, changing the "input tax to be certified" into "input tax". ${ }^{3}$

\section{B. The Deduction of Depreciation and Amortization of Long-Term Assets and the Innovation of Accounting Treatment Directly for Research and Development}

Under the current consumption VAT deduction rules, the long-term assets purchased outward are generally deducted for input VAT as required. In order to encourage R \& D investment, it can be designed to make another deduction of the depreciation amortization of long-term assets directly for research and development. Due to different enterprises, different industries, different equipment may have different depreciation and amortization period and different amortization method, so it may bring the operation difficulties in tax levy. However, regardless of any depreciation and amortization method chosen by the enterprise, the total depreciation and amortization will be unchanged during the depreciation and amortization period. At the same time, the accounting treatment for the depreciation and amortization of long-term assets for research and development can be adjusted, debit: R \& D expenditure, etc., debit: tax payable - input tax amount to be certified, credit: cumulative depreciation or accumulated amortization. After the certification of the tax bureau, "the input tax to be certified" is changed into the "input tax".

The above-mentioned (1) R \& D expenditure and (ii) the VAT deduction for depreciation and amortization of longterm assets directly for research and development are the tax incentives based on innovative behavior rather than that on

\footnotetext{
${ }^{2}$ Source: Statistical Yearbook of Scientific and Technological Activities of Industrial Enterprises.

${ }^{3}$ Accounting entries refer to the ACCOUNTING [2016] No. 22 notice about printing the "VAT accounting regulations" issued by the accounting department of the Ministry of Finance on December 14, 2016.
} 
innovative outcome, which are more conducive to long-term technological innovation incentive effect.

\section{The Deduction of Amortization of Technical Intangible Assets and the Innovation of Accounting Treatment}

The results of innovation are often reflected in the intangible assets of the balance sheet. In order to encourage innovation, the amortization of technical intangible assets 4 can also be designed to be deductible. At the same time, accounting treatment should also be adjusted accordingly. In the amortization, debit: management fees, etc., debit: tax payable - input tax to be certified, credit: cumulative amortization. After the certification of tax bureau, and refill debit: tax payable - VAT payable (input tax), credit: tax payable - input tax to be certified.

At the same time, the above three aspects of the accounting treatment reduces the current profit and loss expense in income processing, which can treated for tax reduction adjustment in the calculation of current taxable income, to avoid deducting the value-added tax but adding corporate income tax. If it does not affect the current profits and losses, e.g. it is included in R \& D expenditure - capital expenditure, manufacturing costs, and based on the tax system simplification, it can be also treated for tax reduction in the calculation of current taxable income of enterprise.

The following is an example to explain the accounting treatment for internal deduction of innovative value-added tax. The depreciation and amortization of Company $\mathrm{A}$ in March $200 \times$ is as follows: Depreciation of the plant is $3,900,000$ yuan, depreciation of the machinery and equipment for production is 4,500,000 yuan, depreciation of the management buildings is 9000000 yuan, depreciation of the equipment directly used for scientific research and development is 5,850,000 yuan, amortization of a new patent technology for production is 750,000 yuan, salary payable is 205,000, of which: 100000 yuan for the production sector, 5 000 yuan for the workshop management staff, 50000 yuan for the company management staff, 20000 yuan for dedicated sales staff, 30000 yuan for scientific researchers. The entries are as follows:

(1) Depreciation of fixed assets:

Debit: manufacturing costs - plant 3900000

$\begin{array}{lr}\text { - Machine equipment } & 4500000 \\ \text { Management costs } & 9000000 \\ \text { R \& D expenditure [5 } 850000 /(1+17 \%)] 5000000\end{array}$
850000

Tax payable - input tax to be certified (5000 $000 * 17 \%)$

Credit : Accumulated depreciation 23250000

\footnotetext{
${ }^{4}$ Only technical intangible assets are related to innovation, and patents and land use rights are unrelated to innovation; if technical intangible assets is directly used for research and development, it has been deducted in the aforementioned (2). But in order to simplify, all the technical intangible assets, whether it is directly used for research and development, can be deducted once again.
}

(2) Amortization of intangible assets: 026

Debit : Manufacturing costs $[750000 /(1+17 \%)] 641$

Taxes payable - input tax to be certified [750 $000 /(1+$ $17 \%) * 17 \%$ ] 108974

Credit: amortization 750,000

(3) Confirmation of salary costs:

Debit: Production costs

100000

$\begin{array}{lc}\text { Manufacturing costs } & 5000 \\ \text { Management costs } & 50000\end{array}$

Sales costs

20000

R \& D expenditure $[30000 /(1+17 \%)] 25641$ 359

Tax payable - input tax to be certified $(25641 * 17 \%) 4$

Credit: Employee wages payable 205000

(4) After certified by the tax bureau,

Debit: Tax payable - VAT payable (input tax) 963333

$(850000+108974+4359)$

Credit: Tax payable - input tax to be certified 963333

\section{The GRADUAL EXPANSION OF VALUE-AdDED TAX DEDUCTION}

In consideration of to the stability of the tax, the abovementioned value-added tax plus deduction based on the promotion of scientific and technological innovation can be gradually implemented step by step. First, we can deduct the cost of internal R \& D labor on the base of current valueadded tax deduction; second, we can add the deduction amount and directly use it for the long-term assets depreciation amortization of research and development; third, we can add other expenses deducted for research and development; fourth, we add the amortization of technical intangible assets deducted.

The above-mentioned internal VAT exemption adding policy can be designed according to the needs of industrial structure adjustment, which can be first implemented among the in the industry for urgent development need, such as emerging strategic industries; and then among the key industry of development priority, such as the implementation of science and technology industries; and finally among the general industry. In the end, regardless of any market entity, for all the expenses and amortization related to Research and development, the input VAT can be calculated for deduction, and take it as a long-term inclusivetype fiscal policy for promotion.

According to the data released by the China National Bureau of Statistics website, China's outlay of research and experimental development is 1416.988 billion yuan in 2015 . If it is deductible, estimated at $17 \%$ tax rate, the burden of 240.888 billion yuan can be reduced for the enterprise in 
research and development, which will greatly encourage business research and development. The increase of amount of VAT deduction, can reduce the cost of enterprise valueadded tax, improve the enthusiasm of enterprises in research and development, promote the transformation and upgrading of industry and the entire economy.

\section{CONCLUSION}

This paper analyzes the nature of VAT deduction and the function of value-added tax optimization economy under the background of China's innovation-driving-development strategy, and puts forward that we should add the internal R \& D labor costs and directly use it for the input VAT deduction in the depreciation and amortization of long-term assets and the amortization of technical intangible assets, to reduce the cost of tax, and adjust the accounting treatment, and to encourage the research and development, promote the scientific and technological progress and boost economic restructuring and upgrading.

\section{REFERENCES}

[1] Li Wenjing, Li Yaotao. Industrial Policy Encourages the Investment of Companies?[J]. China Industrial Economics, 2014 (5): 122-134.

[2] Zhao Guoqin, Gao Fei. The Choice of Fiscal and Tax Policies to Guide the Development of Industry - Based on Panel Data Analysis of Listed Companies [J]. Tax Research, 2016 (10): 2227.

[3] Liu Shangxi, Fan Yixia. Practice of the concept of innovation and development to build innovative and friendly tax system [J]. Tax research, 2016 (10): 3-8.

[4] Chen Xiaoguang. Effective Tax Rate Difference and Efficiency Loss of Value-Added Tax - the enlightenment on the "plan of replacing business tax with value-added tax" [J]. Chinese Social Sciences, 2013 (8): 67-84

[5] Jiang Wei. Value-added Tax Distortions, Productivity Distribution and Resource Misplaced [J]. World Economy, 2016, 39 (5): 54-77 